Research article

\title{
DIFFERENTIATION BETWEEN PSEUDOMONAS AND STENOTROPHOMONAS SPECIES ISOLATED FROM FISH USING MOLECULAR AND MALDI-TOF METHOD
}

\author{
AKSENTIJEVIĆ Ksenija ${ }^{1}$, AŠANIN Jelena ${ }^{2}$, MILIVOJEVIĆ Dušan ${ }^{3}$, ČOLOVIĆ \\ Svetlana ${ }^{4}$, BUTORAC Ana $^{5}$, CINDRIĆ Mario ${ }^{6}$, MIŠIĆ Dušan ${ }^{1 *}$ \\ ${ }^{1}$ Department of Microbiology, Faculty of Veterinary Medicine University of Belgrade, Belgrade, \\ Serbia; ${ }^{2}$ Innovation Center of Faculty of Technology and Metallurgy, University of Belgrade, Belgrade, \\ Serbia; ${ }^{3}$ Laboratory for Microbial Molecular Genetics and Ecology, Institute of Molecular Genetics and \\ Genetic Engineering, University of Belgrade, Belgrade, Serbia; ${ }^{4}$ Laboratory for Human Ecology and \\ Ecotoxicology, Institute of Public Health Belgrade, Belgrade, Serbia; ${ }^{5}$ Central Laboratory, Biocentre Ltd., \\ Zagreb, Croatia; ${ }^{\circ}$ Laboratory for System Biomedicine and Centre for Proteomics and mass spectrometry, \\ "RuđerBošković" Institute, Zagreb, Croatia.
}

(Received 28 April; Accepted 29 June 2016)

For the purpose of precise antibiotic susceptibility testing it is necessary to clearly distinguish Pseudomonas and Stenotrophomonas genera, considering acquired resistance of Pseudomonas species, as well as the intrinsic resistance of Stenotrophomonas species. This is why in the identification of the 51 isolates originated from fish, the following methods were used: standard PCR, 16S rRNA gene sequencing, and MALDI-TOF.

The results of the standard PCR test, 16S rRNA gene sequencing and MALDI-TOF analysis confirmed 35 strains to belong to the Pseudomonas genus. Standard PCR test and VITEK MS device confirmed that 10 strains belong to Stenotrophomonas maltophilia species.

Three strains were positive in both standard PCR tests for Pseudomonas and Stenotrpohomonas. 16S rRNA gene sequencing identified these 3 strains to be $99 \%$ Pseudomonas sp. and 99\% Stenotrophomonas sp. VITEK MS first identified these three strains as $99 \%$ Stenotrophomonas, and in the repeated identification it identified them as $99 \%$ Pseudomonas. MALDI TOF/TOF 4800 Plus device identified these strains as Stenotrophomonas.

Three strains were negative in both standard PCR tests for Pseudomonas and Stenotrpohomonas. 16S rRNA gene sequencing identified these 3 strains to be $99 \%$ Pseudomonas sp. and 99\% Stenotrophomonas sp. VITEK MS first identified these three strains as $99 \%$ Stenotrophomonas, and in the repeated identification it identified them as $99 \%$ Pseudomonas. MALDI TOF/TOF 4800 Plus device identified these strains as Stenotrophomonas.

Although modern test methods that have very high specificity (PCR, 16S rRNA gene sequencing, MALDI TOF) were used in this study, precise differentiation between

\footnotetext{
*Corresponding author: e-mail: dusan@vet.bg.ac.rs
} 
Pseudomonas and Stenotrophomonas species for 6 isolates could not be reached using the above mentioned methods.

Key words: fish, Pseudomonas, Stenotrophomonas, PCR, 16S rRNA, MALDI-TOF

\section{INTRODUCTION}

Antibiotics susceptibility testing in bacteria isolated from fish is significantly more complex compared to the same investigations for bacteria isolated from humans and domestic animals. Fish are colonized with bacteria that are intrinsically resistant to a large number of antibiotics (Stenotrophomonas) and therefore do not have great significance in assaying resistance mechanisms. It is not known what significance or how great the significance is when it comes to the spread of antibiotic resistance genes in the Flavobacterium, Brevundimonas, Plesiomonas, Chryseobacterium, Psychrobacter, Shewanella, Rabnel, Raoultella and Chromobacterspecies, which are an integral part of the microbiome of the skin and guts of the fish. Many of the listed species are genetically related and once belonged to the same genus, so this is the reason why it is difficult to differentiate them, particularly using conventional methods. Most bacteria species originating from fish, require lower temperature (about $22^{\circ} \mathrm{C}-25^{\circ} \mathrm{C}$ ) for their growth, compared to the recommended incubation temperature for disk diffusion and microdilution methods or for $\mathrm{E}$ - test $\left(35^{\circ} \mathrm{C}-37^{\circ} \mathrm{C}, \mathrm{CLSI}, \mathrm{EUCAST}\right)$ [1], which is why it is not known whether the results obtained are valid if the antibiotic susceptibility testing is performed at temperatures lower than recommended. In 2011 EUCAST (European Committee on Antimicrobial Susceptibility Testing) issued a document [2] which serves as the basic guide to differentiate the intrinsic resistance from an acquired resistance in various bacteria species. In this document, only a small number of bacteria species that can be found in fish are listed, these are members of the Pseudomonas, Stenotrophomonas, Yersinia and Enterobactergenera. For Aeromonas only information on the intrinsic resistance was given in the document that was jointly published by EUCAST and the French association of microbiologists [3]. For almost all other bacteria species characteristic for fish, including Vibrio, there is no information on which antibiotics they are intrinsically resistant to, and which resistance may be considered acquired.

Stenotrophomonas is an opportunistic pathogen that is intrinsically more resistant to a large number of antibiotics, including the aminoglycosides, cephalosporins and carbapenems. In contrast, Pseudomonas species are naturally sensitive to most antibiotics to which Stenotrophomonas species are intrinsically resistant. Finding resistance to carbapenems, aminoglycosides and some cephalosporins (cefepime, ceftazidime and cefotaxime) in Psendomonas species isolated from fish has a great epidemiological significance. As Stenotrophomonas maltophilia species once belonged to the Pseudomonas genus, there are significant difficulties when trying to identify and clearly distinct between the Pseudomonas and Stenotrpohomonas genera. Results from the conventional systems, such as API 20 NE (bioMerieux, France) and BBL Crystal Enteric / Nonfermenter ID kit (Becton Dickinson, USA) are not considered 
authoritative in the scientific research field because, even if they are categorized as "excellent" "very good" or "good identification", these systems exhibit a high level of errors in differentiating between Pseudomonas and Stenotrophomonas species [4]. The most common cause of confusion with the classical identification is discrepancy in the oxidase test in Stenotrophomonas species that are oxidase negative, but atypical, positive oxidase test occurs in as many as $20 \%$ of the strains [5]. In addition, some isolates of Pseudomonas species can be oxidase negative. Besides the oxidase test, susceptibility testing to sulfamethoxasole/trimethoprim and intrinsic resistance test to imipenem as typical characteristics of Stenotrophomonas species is being proposed as the main conventional test for distinguishing Stenotrophomonas from Pseudomonas species. However, due to the widespread of acquired resistance of Stenotrophomona sspecies to sulfamethoxasole/trimethoprim, and Pseudomonas species to imipenem, proposed phenotypic tests have also become unreliable. This is why in the recent years exclusively molecular methods [6],and MALDI-TOF [7] are being proposed in order to get precise and clear identification of bacteria isolated from fish. In this research, differentiation of Pseudomonas and Stenotrophomonas species isolated from fish was carried out using standard PCR methods, the 16S rRNA gene sequencing, MALDITOF, as well as some conventional methods.

\section{MATERIAL AND METHODS}

\section{Tested strains of bacteria}

In this study strains of bacteria were isolated from swabs taken from the gills and skin of healthy, live carp, originating from different ponds in Serbia. The strains were isolated in order to study their sensitivity to antibiotics. For the assay, only Gram-negative species were selected, as to test their resistance to carbapenems, aminoglycosides and III and IV generation cephalosporins. Out of 200 isolated strains, in the preliminary, conventional test, 35 strains were suspected to belong to the Pseudomonas genus, 10 to belong to the Stenotrophomonas genus, and 6 strains could not be categorized, actually they were oxidase positive and resistant to sulfamethoxazole/trimethoprim or showed multi-resistance to aminoglycosides, carbapenems and cephalosporins, so it was necessary to rule out the suspicion that they belong to the Stenotrophomonas genus.

\section{Isolation and identification using conventional methods}

Culturing of swabs was performed on UTI agar (Urogenital tract infections chromogenic agar, HI Media) from where pure cultures were subcultivated and maintained on Columbia blood agar supplemented with 5\% sheep blood (bioMerieux, France). The plates were incubated at a $25^{\circ} \mathrm{C}$. All isolated strains were assayed in the oxidase test using oxidase reagent dropper (Becton Dickinson, USA). The diagnostic susceptibility test to sulfamethoxasole/trimethoprim and imipenem was performed using disk diffusion method on Mueller Hinton agar (Becton Dickinson, USA) with discs manufactured by Becton Dickinson, as well as by using $\mathrm{E}$ test strips of the 
same antibiotic (bioMerieux), in order to determine the MIC value, also on Mueller Hinton agar. Reading and interpretation of the results were carried out according to the EUCAST recommendations (2016).

\section{Standard PCR}

DNA isolation from investigated strains was carried out using the boiling method. In short: 1-2 colonies of overnight culture were resuspended in $1 \mathrm{~mL}$ PBS buffer (Dulbecco's, Serva) in Eppendorf tubes of $1.5 \mathrm{~mL}$ volume. After vortexing, the suspension was centrifuged at 13,200 rpm for 5 minutes at RT. The supernatant was discarded, and the pellet was resuspended in $100 \mu \mathrm{l}$ of TE buffer (Thermo Scientific). Subsequently, the tubes with TE buffer were soaked in boiling water for 10 minutes, incubated on ice for 1 minute, and the remaining content that contains the genomic DNA was resuspended and transferred to $900 \mu \mathrm{l}$ of TE buffer. The isolated DNA was stored at $-20^{\circ} \mathrm{C}$. In order to precisely determine if it belongs to the Psendomonas genus the PCR method that was previously described [8] was used. Primers (Invitrogen) had the following sequences: PA-GS-F 5'-GACGGGTGAGTAATGCCTA-3 and PAGS-R 5'CACTGGTGTTCCTTCCTATA - 3', and the size of the amplified product was $618 \mathrm{bp}$. The PCR mixture in an amount of $25 \mu \mathrm{l}$ consisted of $2 \mathrm{mM} \mathrm{MgCl}_{2}, 1 \mathrm{x}$ Hot Start PCR Buffer (200 mM Tirs-HCl pH 8,3; $200 \mathrm{mM} \mathrm{KCl;} 50 \mathrm{mM}\left(\mathrm{NH}_{4}\right) 2 \mathrm{SO} 4$; Thermo Scientific), $0.4 \mathrm{mM}$ deoxynucleoside triphosphates each (Thermo Scientific), $0.4 \mu \mathrm{M}$ of each primer, $1 \mathrm{U}$ Maxima Hot Start Taq Polymerase (Thermo Scientific) and $2 \mu \mathrm{l}$ of DNA. Conditions of PCR reactions took place according to the following scheme: initial denaturation of $95^{\circ} \mathrm{C}$ for 4 minutes, 25 cycles of denaturation at $95^{\circ} \mathrm{C}$ for 30 seconds, annealing $54^{\circ} \mathrm{C} 30$ seconds, extension $72^{\circ} \mathrm{C}$ for 1 minute and a final extension $72^{\circ} \mathrm{C}$ for 5 minutes. As a positive control P. aeruginosa ATCC 27853 strain was used, and as a negative control S. maltophilia ATCC 13637.

For precise determination of the investigation strains of the Stenotrophomonas genus the method previously described [9] was used. Sequences of the applied primers (Invitrogen) were as follows: F 5'-GCTGGATTGGTTCTAGGAAAACGC-3'and R 5'-ACGCAGTCACTCCTTGCG -3', and the size of the amplified product was 278 bp. The PCR mixture in an amount of $25 \mu \mathrm{l}$ was composed of $1 \mathrm{mM} \mathrm{MgCl}, 1 \times$ x Hot Start PCR Buffer (200 mM Tirs-HCl pH 8,3; 200 mM KCl; 50 mM (NH4) ${ }_{2} \mathrm{SO}_{4}$; Thermo Scientific), $0.2 \mathrm{mM}$ deoxynucleoside triphosphates each (Thermo Scientific), $0.2 \mu \mathrm{M}$ of each primer, 2 U Maxima Hot Start Taq Polymerase (Thermo Scientific) and $2 \mu l$ of DNK. Conditions of the PCR reaction took place according to the following scheme: initial denaturation at $95^{\circ} \mathrm{C}$ for 5 minutes, 30 cycles of denaturation at $95^{\circ} \mathrm{C}$ for 45 seconds, $55^{\circ} \mathrm{C}$ annealing for $30 \mathrm{sec}$, extension $72^{\circ} \mathrm{C}$ for 45 seconds and a final extension at $72^{\circ} \mathrm{C}$ for 10 minutes. 


\section{Isolation and characterization of bacterial isolates by I6SrRNA gene sequencing}

Genomic DNA from isolated strains was extracted (Kapa Express Extract Kit, KapaBiosystems, Wilmington, MA, USA) and 16S ribosomal RNA (16S rRNA) gene was amplified by polymerase chain reaction (PCR) using universal bacterial primers 27f and 1492r [10]. Obtained PCR products were sequenced using Applied Biosystems 3130 Genetic Analyzer (Foster City, CA, USA) and sequences were analyzed and assembled by SeqMan Pro software (DNASTAR Inc., Madison, WI, USA). The BLASTN program (NCBI, http://www.ncbi.nlm.nih.gov ) [11] was used for sequences similarity search.

\section{Identification using MALDI-TOF method}

Identification of strains using MALDI-TOF method (Matrix-assisted laser desorption/ ionization time of-flight mass spectrometry) was performed on VITEK MS device (bioMerieux Industry, France). To prepare strains VITEK MS-CHCA matrix, (bioMerieux) was used, and to read the result database VITEK MS Knowledge Base V2.0 - Industry Use was used. To calibrate the device, E. coli ATCC 8739 calibration strain was used. A small number of strains was also investigated on MALDI TOF/ TOF 4800 Plus (AB SCIEX, USA), besides being assayed on VITEK MS device. The bacteria were identified by MALDI MS/MS biotypization protocol described at http:/ / rapidcell.proteinreader.com/maldi-msms-biotypization-protocol/[12].

\section{RESULTS}

Out of the 51 strains investigated in conventional tests, 35 were oxidase positive, most were resistant to sulfamethoxasole/trimethoprim with obtained MIC values > $32 \mu \mathrm{g} / \mathrm{mL}$ and were suspected to belong to the Pseudomonas genus. A total of 10 strains were negative in oxidase test and were sensitive to sulfamethoxasole/trimethoprim with obtained MIC values $<4 \mu \mathrm{g} / \mathrm{mL}$, and they were suspected to belong to the Stenotrophomonas genus. A total of 6 strains were oxidase positive with a delayed (slow) oxidase reaction, and in the readings to sulfamethoxazole/trimethoprim sensitivity after $18^{\mathrm{h}}$, strains were clearly sensitive, with MIC values of $<4 \mu \mathrm{g} / \mathrm{mL}$ and when reread after 6 more hours incubation, they were clearly resistant, with MIC values $>32$ $\mu \mathrm{g} / \mathrm{mL}$. This part of the test was repeated several times, and identical results were always obtained - uneven sensitivity in just $6^{\mathrm{h}}$ difference in the length of incubation. Identical results were obtained while repeating the above mentioned tests using the disk diffusion method, where the zone around the sulfamethoxazole/trimethoprim disk in readings after $18^{\mathrm{h}}$ of incubation was $>16 \mathrm{~mm}$, and in re-reading after $2-6^{\mathrm{h}}$, the area was $0 \mathrm{~mm}$. These strains were resistant to carbapenems, III and IV generation of cephalosporins, and aminoglycosides. 
Based on the results of standard PCR test, 16S rRNA gene sequencing and MALDITOF analysis, 35 strains that were suspected of belonging to Pseudomonas, were confirmed to belong to that genus. In the standard PCR assay, these strains gave positive results in the form of the presence of the desired PCR product the size of 618 bp (Figure 1). Out of 35 strains, 3 stains were identified as P. aeruginosa with 99\% accuracy, in both assays performed: 16S rRNA gene sequencing analysis and using VITEK MS device. In the 16S rRNA gene sequencing, two more strains were identified as P.fluorescens with $99 \%$ accuracy, and VITEK MS identified one out of the two strains as P.fluorescens ( $99 \%$ accuracy), while the other was not clearly identified up to the species, but it was confirmed to belong to the Pseudomonas genus. The remaining 30 strains were identified as Psendomonas spp. with 99\% accuracy with both 16S rRNA gene sequencing and using VITEK MS device.

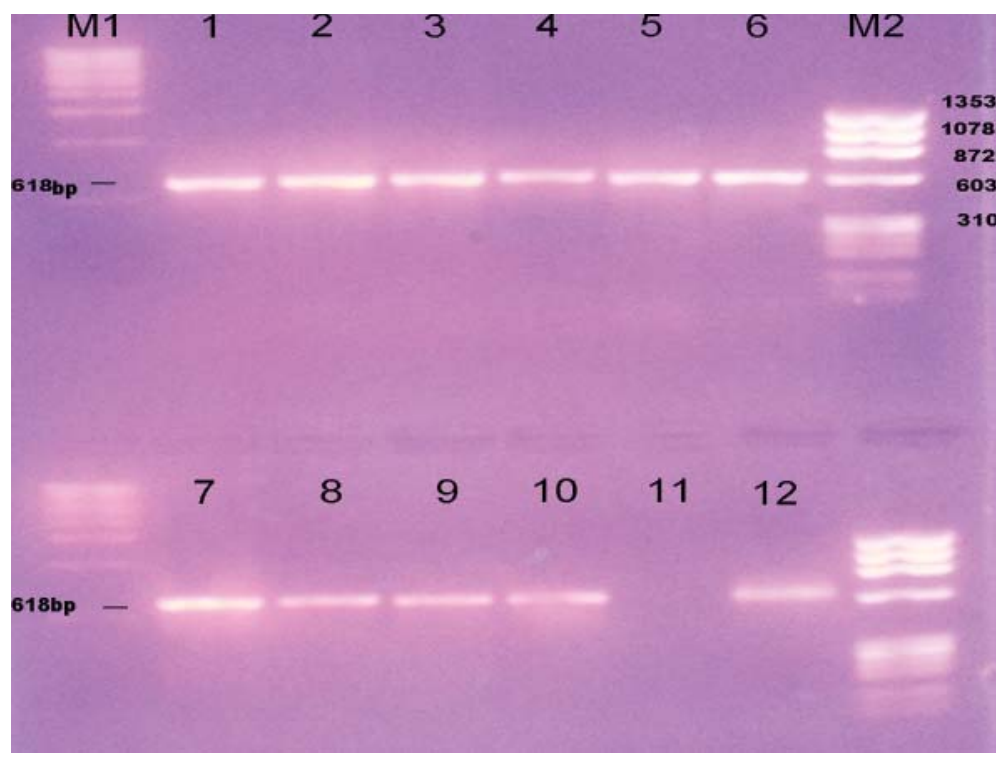

Figure 1. Agarose gel electrophoresis with PCR products of standard PCR for Psendomonas genus identification: M1- DNA Standard $1 \mathrm{KBp}$ DNA ladder (SERVA); lanes 1-5 strains identified as Pseudomonas spp with PCR products size 618-bp; lane 6 positive control P.aeruginosa ATCC 27853; M2-ФX174 DNA/BsuRI (HaeIII) Marker, 9 (Fermentas); lanes 7-10 strains identified as Pseudomonas spp; lane 11 negative control S. maltophilia ATCC 13637; lane 12 positive control P.aeruginosa ATCC 27853

In a standard PCR assay, 10 strains which were suspected of belonging to the Stenotrophomonas genus gave a positive PCR product of $278 \mathrm{bp}$ in size, which is characteristic of this genus (Figure 2). These strains were not analyzed by $16 \mathrm{~S}$ RNA gene sequencing. Identification on the VITEK MS device, with $99.9 \%$ accuracy confirmed that these 10 strains belong to Stenotrophomonas maltophilia species (Table 1).

Out of the 6 remaining strains for which there was doubt to what species and genus they belonged, three strains yielded positive results in PCR reactions for both assayed genera. These six disputable isolates were further identified by $16 \mathrm{~S}$ rRNA gene sequencing (1300 bp) (Table 2). 16S rRNA gene sequences of isolates shared $99 \%$ 
$-100 \%$ of the $16 \mathrm{~S}$ rRNA gene sequence identity with their closest matching entries in GenBank.

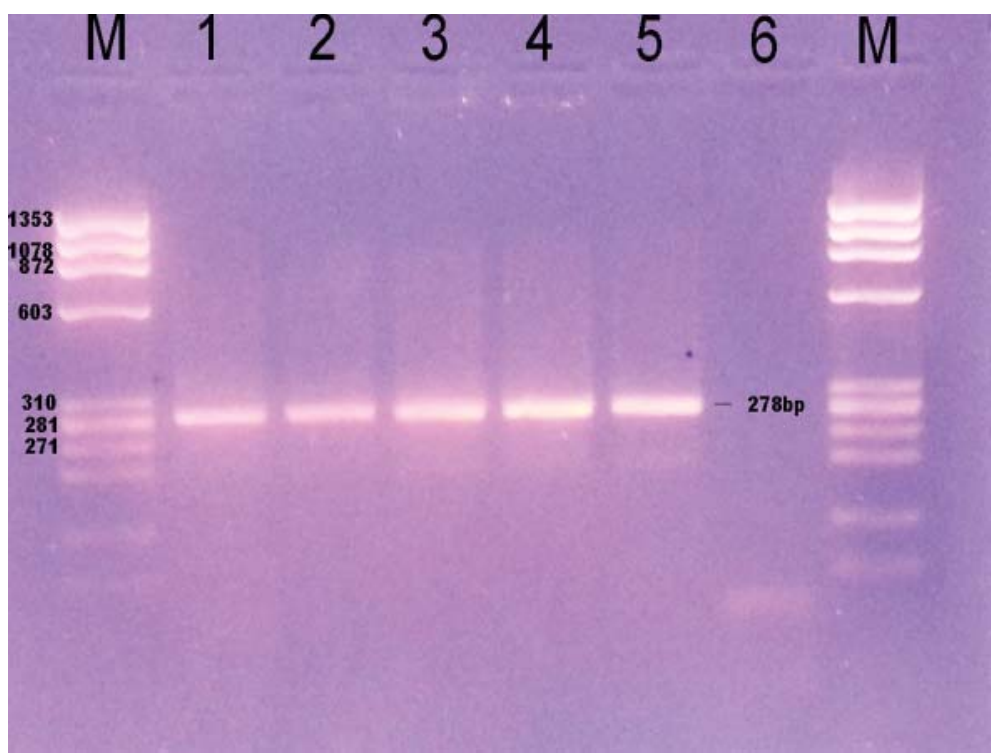

Figure 2. Agarose gel electrophoresis with PCR products of standard PCR for Stenotrophomonas genus identification: M-ФX174 DNA/BsuRI (HaeIII) Marker, 9 (Fermentas); lanes 1-4 strains identified as Stenotrophomonas with PCR products size 278-bp; lane 5 positive control $S$. maltophilia ATCC 13637; lane 6 negative control P.aeruginosa ATCC 27853

Table 1. Results of the identification of investigated strains using standard PCR and MALDI TOF

\begin{tabular}{lccc}
\hline Isolate & $\begin{array}{c}\text { Standard PCR } \\
\text { Pseudomonas spp. }\end{array}$ & $\begin{array}{c}\text { Standard PCR } \\
\text { Stenotrophomonas spp. }\end{array}$ & VITEK MS \\
\hline $\begin{array}{l}\text { Pseudomonas spp. } \\
35 \text { isolates }\end{array}$ & $35 / 35$ & $0 / 35$ & $35 / 35$ \\
$\begin{array}{l}\text { Stenotrophomonas spp. } \\
\text { 10 isolates }\end{array}$ & $0 / 10$ & $10 / 10$ & $10 / 10$ \\
\hline
\end{tabular}

For these strains PCR reaction was repeated 3 times, and each time, all three strains were double positive, ie. the PCR products contained both- 618 bp Pseudomonas fragment, and 278 bp Stenotrophomonas fragment. Positive and negative controls in all replications were valid (Figure 3). In the 16S rRNA gene sequencing each of the three strains was identified as 99\% Pseudomonas sp. and 99\% Stenotrophomonas sp., respectively. In other words same as in the PCR method, these strains were categorized with $99 \%$ accuracy as members of both genera. These three strains VITEK MS in the first identification identified as 99\% Stenotrophomonas and in the repeated identification it identified them as 99\% Pseudomonas. The MALDI TOF/TOF 4800 Plus device identified these strains as Stenotrophomonas. 


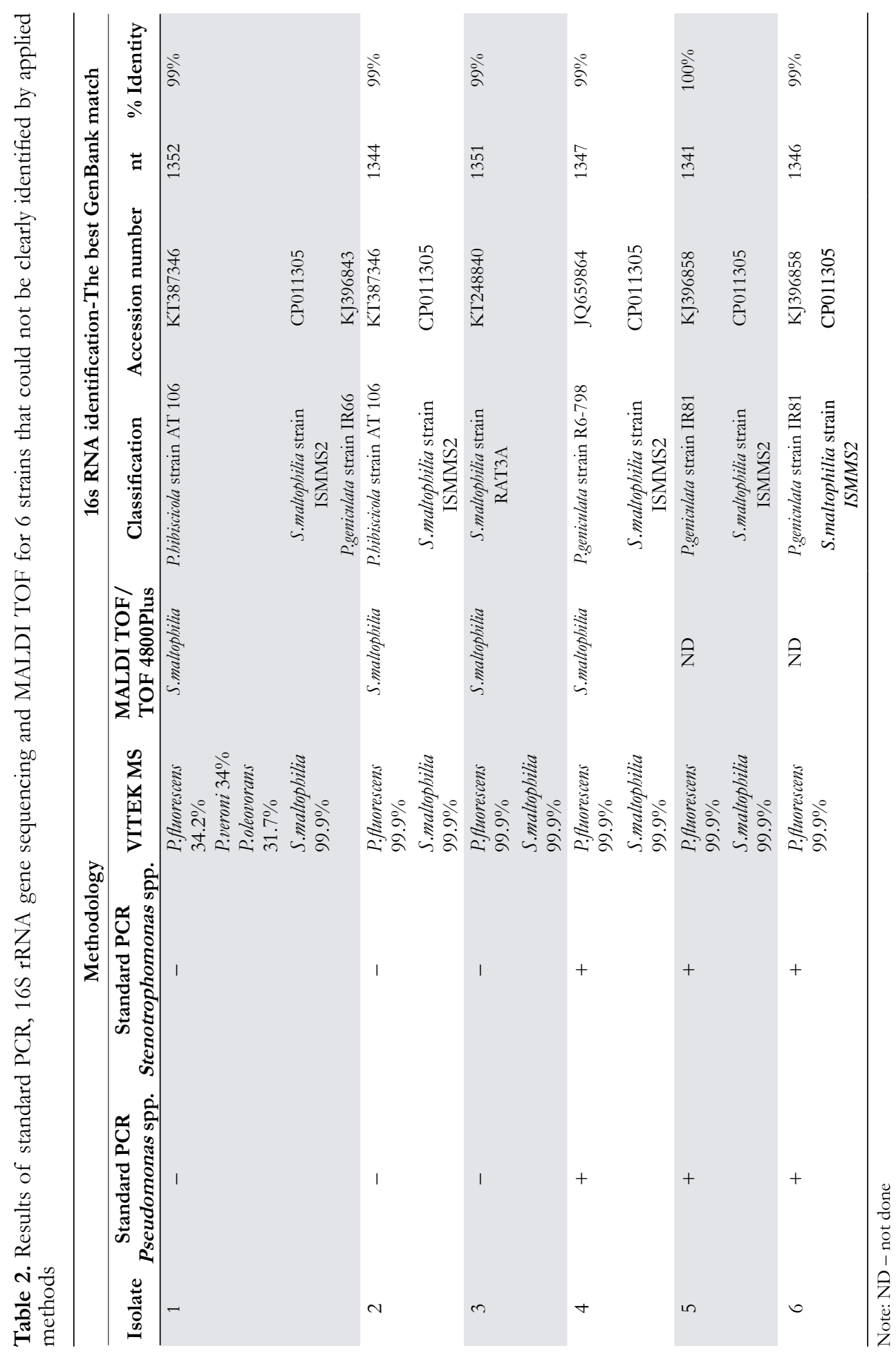




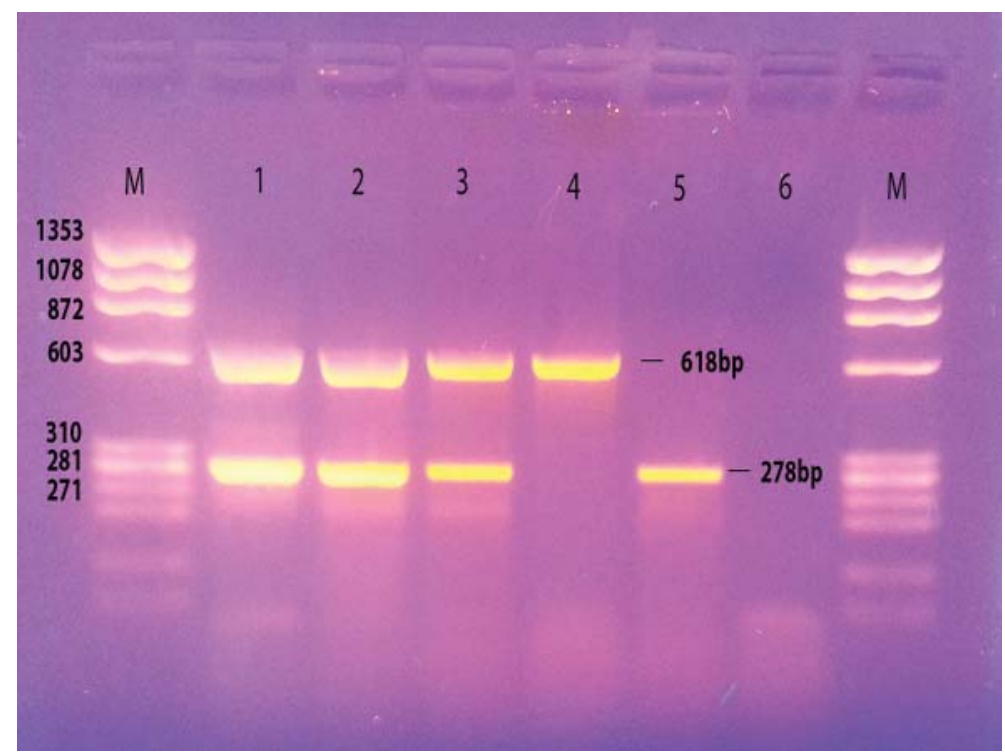

Figure 3. Agarose gel electrophoresis with PCR products obtained in multiplex PCR for Pseudomonas and Stenotrophomonas (for 3 unidentified strains): lane M- $Ф X 174$ DNA/BsuRI (HaeIII) Marker, 9 (Fermentas); lanes 1-3 strains positive on both genera with 618 and 278 bp PCR products; lane 4 P.aeruginosa ATCC 27853; lane 5 S. maltophilia ATCC 13637; lane 6 negative control for PCR.

The remaining three strains were negative in the standard PCR, actually they did not belong to either Pseudomonas or Stenotrophomonas genera. PCR method was repeated 3 times for these strains as well, and each time all three strains were negative for the requested PCR products. However, in the $16 \mathrm{~S}$ rRNA gene sequencing each of the three strains was identified as 99\% Pseudomonas sp. and 99\% Stenotrophomonas sp., actually, based on 16S rRNA gene sequencing these strains were identified as belonging to both genera. VITEK MS device identified these three strains as 99\% Stenotrophomonas in one identification, and as 99\% Pseudomonas in the other. MALDI TOF/TOF 4800 Plus device identified these strains as both Stenotrophomonas.

\section{DISCUSSION}

Given the fact that resistance in bacteria isolated from fish has been drawing great attention in scientific and professional circles in the recent years, there is growing literature about this research topic being published in reputable scientific journals. However, the validity of these results may be questioned from various aspects. One of the papers [13] showed the results of an extremely worrying resistance in bacteria isolated from sharks located in the Atlantic Ocean. Isolated strains mentioned in this paper were resistant to a great number of antibiotics that are used exclusively in the human medical practice, for example, piperacillin, ceftazidime and cefotaxime. 
However, what is arguable is that all isolates in this paper that were tested to antibiotics sensitivity were not precisely identified and were presented only as Gram-negative bacilli. In this aspect, it is possible that the results shown in this paper were of intrinsic resistance to listed antibiotics. On the other hand, although intrinsically resistant to carbapenems, aminoglycosides, penicillins and cephalosporins, Stenotrophomonas can carry plasmids with genes for TEM [14] and CTX-M [15] beta-lactamases that have extremely great importance in the resistance of bacteria isolated from people. This is why it is important to accurately identify the Stenotrophomonas and for the research on the resistance found in these species to be redirected to plasmids and the aforementioned beta-lactamases. In the papers written by Spilker and Gallo [8.9] it was claimed that designed primers and proposed PCR cycle conditions guarantee to obtain highly specific results with 100\% accuracy. In our study, the 3 strains showed positive findings and the required PCR products for both genera, which indicates a relatively high nonspecificity of this method and this occurred in $5.88 \%$ of the strains. Using standard PCR method it was not determined if 3 of the strains belonged to either of the genus so it could also be rated as an error or non-specificity of the method, because $16 \mathrm{~S}$ rRNA gene sequencing and MALDI TOF methods identified these strains as Pseudomonas and/or Stenotrophomonas. These results emphasize the important point that effective identification by the $16 \mathrm{~S}$ rRNA gene sequencing is not necessarily a sufficient criterion to guarantee species identity. So, if these 6 strains all generated nonspecific results, or an error in the standard PCR, it means that standard PCR non-specificity in this research has appeared in $11.76 \%$ of the strains. However, the 6 debatable strains could not be accurately identified to the end and therefore the findings obtained in a standard PCR cannot be clearly interpreted for these 6 strains. Thus, although $16 \mathrm{~S}$ rRNA gene sequences can be used routinely to distinguish and establish relationships between genera and well-resolved species, very recently diverged species may not be recognizable.

MALDI TOF is considered one of the most accurate methods in the identification of bacterial species. However, it is known that in the analysis of the detected sequence of proteins, which database is used plays an important part. In this sense, a vague finding does not mean that the MALDI TOF is a nonspecific method, but the database has not been fully updated. In this study MALDI TOF device intended for the identification of bacteria isolated from a variety of waters: from wells, rivers, seas, etc. was used, so the database for both devices was comprehensively updated for types of bacteria found in waters, and therefore in fish. However, in this field of study research has probably not yet determined or clearly defined all the protein sequences of all species of bacteria that can be found in fish because the databases obviously recognize joint sequences for Pseudomonas and Stenotrophomonas.

\section{CONCLUSIONS}

Although for this research modern test methods that have very high specificity for this field of study (PCR, 16s rRNA gene sequencing, MALDI TOF) were used, it is 
obvious that these methods have not been sufficiently perfected yet so that precise results could be obtained in 100\% of cases; in other words, precise differentiation of Pseudomonas and Stenotrophomonas species could not be obtained using the listed methods. For the standard PCR it is necessary to find the gene sequences in Pseudomonas and Stenotrophomonas that do not have similarities, and to design a new, more specific primer pairs based on which these genera could be precisely distinguished. Although the $16 \mathrm{~S}$ ribosomal RNA (rRNA) gene sequencing is a well-established method for studying phylogeny and taxonomy of samples from complex microbiomes or environments that are difficult or impossible to study, there are certain cases that this methodology is best to combine with the biochemical or other identification approaches to yield the definite answer about the identity of a particular bacterial isolate. In MALDI TOF method, it is necessary to also determine the precise protein sequences that are unique to the Pseudomonas and to the Stenotrophomonas species.

\section{Acknowledgment}

This study was supported by a grant from the Ministry of Education, Science and Technological Development of the Republic of Serbia Project No. TR 31079. We would like to show our gratitude to Mr Sci Drina Topalov, director of Konzilijum Laboratories for assistance with Vitek MS identification of bacterial strains.

\section{Authors' contributions}

$\mathrm{AK}, \mathrm{AJ}, \mathrm{MD}$ and $\mathrm{MD}$ carried out the molecular genetic studies, participated in the sequence alignment and drafted the manuscript. ČS, BA and CM carried out the MALDI-DOF. AK, AJ and MD participated in the design of the study and performed the statistical analysis. AK, AJ, MD, MD, ČS, BA and CM conceived of the study, and participated in its design and coordination and helped to draft the manuscript. All authors read and approved the final manuscript.

\section{Declaration of conflicting interests}

The author(s) declared no potential conflicts of interest with respect to the research, authorship, and/or publication of this article.

\section{REFERENCES}

1. Urumova V: Investigations on the resistance of porcine commensal E. coli isolates to beta lactams, Acta Vet (Beograd) 2015, 65 (4), 538-547.

2. Leclercq R, Canto'n R, Brown DFJ, GiskeCG, Heisig P, MacGowan AP, Mouton JW, Nordmann P, Rodloff AC, Rossolini GM, Soussy CJ, Steinbakk M, Winstanley TG, 
Kahlmeter G: EUCAST expert rules in antimicrobial susceptibility testing, Clin Microbiol Infect 2013, 19: 141-160.

3. EUCAST and Comite de l'antibiogramme de la Societe Francaise de Microbilogie: Recommandations 2015.

4. Wellinghausen N, Köthe J, Wirths B, Sigge A, Poppert S: Superiority of Molecular Techniques for Identification of Gram-Negative, Oxidase-Positive Rods, Including Morphologically Nontypical Pseudomonas aeruginosa, from Patients with Cystic Fibrosis, J Clin Microbiol 2005, 43(8):4070-5.

5. Carmody LA, Spilker T, Li Puma JJ: Reassessment of Stenotrophomonas maltophilia phenotype, J Clin Microbiol 2011, 49:1101-1103.

6. Bosshard PP, Zbinden R, Abels S, Bo"ddinghaus B, Altwegg M, Bo"ttger EC: 16S rRNA Gene Sequencing versus the API 20NE system and the VITEK 2 ID-GNB Card for identification of non fermenting Gram Negative bacteria in the clinical laboratory, J Clin Microbiol 2006, 44 (4): 1359-1366.

7. Mellmann A, Cloud J, Maier T, Hall G, Wilson D, Keckevoet U, Ramminger I, IwenP, Dunn J, La Sala P, Kostrzewa M, Harmsen D:Evaluation of Matrix-Assisted Laser Desorption Ionization-Time-of-Flight Mass Spectrometry in Comparison to 16S rRNA Gene Sequencing for Species Identification of Non fermenting Bacteria, J Clin Microbiol 2008, 46 (6);1946-1954.

8. Spilker T, Coenye T, Vandamme P, Li Puma JJ: PCR-Based Assay for Differentiation of Pseudomonas aeruginosa from Other Pseudomonas Species Recovered from Cystic Fibrosis Patients, J Clin Microbiol 2004, 42(5): 2074-2079.

9. Gallo SW, Ramos PL, Sanchez FCA, Oliveira SD: A specific polymerase chain reaction method to identify Stenotrophomonas maltophilia, Mem Inst Oswaldo Cruz. 2013, 108(3): 390-391.

10. Lane DJ: 16S/23S rRNA sequencing. In: Nucleic acid techniques in bacterial systematic. Wiley, Chichester; 1991, 115-175.

11. Altschul SF, Madden TL, Schaffer AA, Zhang J, Zhang Z, Miller W, Lipman DJ: Gapped BLAST and PSI-BLAST: a new generation of protein database search programs, Nucleic Acids Res 1997, 25: 3389-3402.

12. http://rapidcell.proteinreader.com/maldi-msms-biotypization-protocol/.

13. Blackburn JK, Mitchell MA, Blackburn MCH, Curtis A, Thompson BA: Evidence of Antibiotic Resistance in Free-Swimming, Top-Level Marine Predatory Fishes J. Zoo Wildl Med 2010, 41(1):7-16.

14. Naiemi N, Duim B, Bart A: A CTX-M extended-spectrum $\beta$-lactamase in Pseudomonas aeruginosa and Stenotrophomonas maltophilia J Med Microbiol, 2006, 55: 1607-1608.

15. Maravić A ,Skočibušić M, Fredotović Ž ,Cvjetan S, Šamanić I, Puizina J: Characterization of Environmental CTX-M-15-Producing Stenotrophomonas maltophilia, Antimicrob Agents Chemother 2014, 58(10): 6333-6334. 


\section{DIFERENCIJACIJA PSEUDOMONAS I STENOTROPHOMONAS VRSTA IZOLOVANIH IZ RIBA PRIMENOM MOLEKULARNIH METODA I MALDI-TOF METODE}

AKSENTIJEVIĆ Ksenija, AŠANIN Jelena, MILIVOJEVIĆ Dušan, ČOLOVIĆ Svetlana, BUTORAC Ana, CINDRIĆ Mario, MIŠIĆ Dušan

S obzirom na značaj stečene rezistencije Pseudomonas vrsta, kao i na intrinzičnu rezistenciju Stenotrophomonas vrsta, a u cilju preciznog ispitivanja osetljivosti na antibiotike, neophodna je jasna diferencijacija pripadnika ovih rodova bakterija. U tom cilju su u identifikaciji 51 izolata poreklom od riba korišćene metode: standardni PCR, 16S rRNA sekvenciranje gena, MALDI-TOF.

Rezultati standardnog PCR testa, 16S rRNA sekvenciranja gena i MALDI-TOF analize su za 35 sojeva potvrdili pripadnost rodu Pseudomonas. Standardnim PCR testom i primenom aparata VITEK MS utvrđeno je da 10 sojeva pripada vrsti Stenotrophomonas maltophilia.

U 16S rRNA sekvenciranju gena 3 soja koja su bila pozitivna u oba standardna PCR testa identifikovana su kao 99\% Pseudomonas sp. i 99\% Stenotrophomonas sp. VITEK MS je ova tri soja u prvoj identifikaciji identifikovao kao 99\% Stenotrophomonas, a u ponovljenoj identifikaciji kao 99\% Pseudomonas. Ti sojevi su na aparatu MALDI TOF/TOF 4800 Plus bili identifikovani kao Stenotrophomonas.

U 16S rRNA sekvenciranju gena tri soja koja su bila negativna u oba standardna PCR testa su identifikovana kao 99\% Pseudomonas sp. i 99\% Stenotrophomonas sp. Aparat VITEK MS je ova tri soja identifikovao u jednoj identifikaciji kao 99\% Stenotrophomonas, a u drugoj identifikaciji 99\% kao Pseudomonas. Ti sojevi su na aparatu MALDI TOF/ TOF 4800 Plus bili identifikovani kao Stenotrophomonas.

Iako su u ovom istraživanju korišćene savremene metode ispitivanja koje imaju vrlo visoku specifičnost (PCR, 16s rRNK sequencing, MALDI TOF) precizna diferencijacija Pseudomonas i Stenotrophomonas vrsta nije mogla biti postignuta. 